\title{
Assessment of Natural Radioactivity Levels and Radiation Dose Rate in Some Soil Samples from Historical Area, AL-RAKKAH, Saudi Arabia
}

\author{
K. S. Al Mugren \\ Physics Department, Faculty of Sciences, Princess Nourah Bint Abdulrahman University, Riyadh, Saudi Arabia \\ Email: ksalmogren@pnu.edu.sa
}

Received 26 March 2015; accepted 29 April 2015; published 4 May 2015

Copyright (C) 2015 by author and Scientific Research Publishing Inc.

This work is licensed under the Creative Commons Attribution International License (CC BY). http://creativecommons.org/licenses/by/4.0/

(c) (i) Open Access

\begin{abstract}
This study aims to determine the activity concentrations of naturally occurring, technically-enhanced levels of radiation and the gamma absorbed dose rates in soil samples collected across the land scape of historical area which discovered in east of Saudi Arabia at 2009 G, Called ALRAKKAH. By using an HPGe detector gamma-ray spectrometer, the activity concentrations of ${ }^{226} \mathrm{Ra}$ ${ }^{232} \mathrm{Th}$ and ${ }^{40} \mathrm{~K}$ were found in surface soil samples ranged from $17.4 \pm 1.2 \mathrm{~Bq} / \mathrm{kg}$ to $28.3 \pm 2.3 \mathrm{~Bq} / \mathrm{kg}$ with an average value of $23 \pm 1.6 \mathrm{~Bq} / \mathrm{kg}$, ranging from $1.1 \pm 1.8 \mathrm{~Bq} / \mathrm{kg}$ to $81.0 \pm 1.7 \mathrm{~Bq} / \mathrm{kg}$ with the average value $20 \pm 1.4 \mathrm{~Bq} / \mathrm{kg}$ and from $218 \pm 11 \mathrm{~Bq} / \mathrm{kg}$ to $255 \pm 18 \mathrm{~Bq} / \mathrm{kg}$, with the mean value of $233 \pm 12 \mathrm{~Bq} / \mathrm{kg}$ respectively. The mean radium equivalent $\left(\mathrm{Ra}_{\mathrm{eq}}\right)$ and outdoor radiation hazard index $\left(\mathrm{H}_{\mathrm{ex}}\right)$ for the area under study were determined as $69.52 \mathrm{~Bq} / \mathrm{kg}$ and 0.16 respectively. The total absorbed dose rate due to three primordial radionuclides lies in the range of 17.74-72.24 $\mathrm{nGy} \cdot \mathrm{h}^{-1}$ with a mean of $32.69 \mathrm{nGy} \cdot \mathrm{h}^{-1}$, which yields total annual effective dose of $0.37 \mathrm{mSv} \cdot \mathrm{y}^{-1}$. The measured values are comparable with other global radioactivity measurements and are found to be safe for public and environment. The baseline data of this type will almost certainly be of importance in making estimations of population exposure.
\end{abstract}

\section{Keywords}

Soil, Gamma Ray Spectroscopy, Radioactivity, Dose Rate, Alrakkah, Saudi Arabia

\section{Introduction}

During the past few years, growing attention has been devoted to studying the effect of natural radioactivity. We 
are primarily exposed to ionizing radiations emitted from natural and man-made sources. Natural radiations originate from the interaction of cosmic ray particles with the atmospheric elements and naturally occurring radioactive elements found in the earth's crust [1]. The exposure of the public to natural sources of radiation has been estimated by the [2] UNSCEAR, 1988 which concluded an effective average annual dose equivalent to 2.4 $\mathrm{mSv} \cdot \mathrm{y}^{-1}$ per person.

In soil, the natural radioactivity concentrations determine both natural and man-made sources which are important in radiological monitoring and radiation dose assessment for public. There have been many surveys conducted to determine the background levels of radionuclides in soils, which can in turn be related to the absorbed dose rates in air. All of these spectrometric measurements indicate that the three components of the external radiation field, namely from the gamma-emitting radionuclides in the ${ }^{238} \mathrm{U}$ and ${ }^{232} \mathrm{Th}$ series and ${ }^{40} \mathrm{~K}$, make approximately equal contributions to the externally incident gamma radiation dose to individuals in typical situations both outdoors and indoors [3] UNSCEAR 2000. Studies of natural radioactivity are necessary not only because of their radiological impact, but also because they act as excellent biochemical and geochemical tracers in the environment. Also, studies of U-series radionuclides present in nature have been of particular interest due to their relatively high biological mobility [4]. There is a lot of literature on the levels of natural radiation from soil [5]-[12]. However, the number of studies made in the Arabian Gulf is comparatively limited [13]-[17].

The aim of the present work was to determine the activity concentrations of ${ }^{226} \mathrm{Ra}$, ${ }^{232} \mathrm{Th}$ and ${ }^{40} \mathrm{~K}$ in the soil samples from a historical area which was discovered in east of Saudi Arabia at 2009 G, Called Al-RAKKAH. In order to understand the occurrence and distribution of natural radionuclides of soil samples in area under investigation and evaluate potential health hazards, the representative level index, $\mathrm{I}_{\gamma \mathrm{r}}$, the radium equivalent activity $\left(\mathrm{Ra}_{\mathrm{eq}}\right)$, and the annual effective dose equivalent (AEDE) in air for all soil samples were estimated to assess the contribution of this radionuclide to public exposure.

\section{Materials and Methods}

\subsection{Samples Collection and Preparation}

In order to measure the natural radioactivity in soil, surface soil (about $0-10 \mathrm{~cm}$ ) 33 samples were collected using hand auger from 7 regions ((a) North, (b) Center, (c) South, North-East (NE), North-West (NW), South-East (SE), South-West (SW) and East (E)).

AL-RAKKAH is an ancient village dating back to the period of early Islam, located on an area of 108,000 square meters in the middle of the road between the cities of Al Khobar and Dammam, eastern Saudi Arabia and it is one of the most important archaeological sites in the Eastern Province, and also located between two roads coastal and speedy, that link the two cities. It is also located near the fertilizer plant (SAFCO) previously and this was known as the site during a comprehensive survey of sites relics in 1976 and holds the No. (105/208). (Dr Ali Ghabban, Vice President for Antiquities and Museums of the General Authority for Tourism and Antiquities at a news conference Monday, 08/02/2010 in the city of Khobar) [18]. He noted the site discovery time on 12/08/1976 G during the survey work carried out by the agency of Antiquities and Museums, and took No. (105/208) as income property within the site Aramco several years ago. The site covers some sand dunes which are also covered with desert shrubs and devoid of rock formations; it is easy flat, with rising higher hills about 12.46 meters above sea level, while the low-lying areas rises at a rate of 8.5 meters.

Location is mainly residential belonging to the period of early Islam and the Umayyad period and perhaps the beginning of the Abbasid period, through reading pieces of pottery, porcelain, glass, steatite and metal pieces that can be returned for two centuries, the first and second Islamic.

The effects of the site:

- can distinguish three hills head of archaeological excavation site; first is located on the north side has been given the name of the area (a), and the second in Center and carry the name of the area (b), and third in the South has been named area (c).

- spread on the surface of the site, particularly in the area of the ancient hills of breaking pottery, porcelain, glass, can the percentage back to the early Islamic period, as you can see, extensions built with stone walls in all directions.

Exploration

- to document the process of capturing and processing the surface and the process of archaeological excavation contour map was prepared for the entire site; other retinal map divides the target site to dig a network boxes, each rib 22:00 with a break all boxes with width of one meter.

- archaeological survey was conducted to the surface of the site which picked up samples of surface in the 
light of the results of this survey were selected on the region by the most points to start the drilling process.

- 24 were drilled square in the region (a) and a similar number in the region (b), has been digging Saudi team from the Archaeological Office in Dammam and under the supervision and follow-up of the sector of Antiquities and Museums Authority.

- the are close to each cluster of homes of the three that make up the village water system consisting of a well-circular shape folded stones medium-sized and irregular in its upper part and stones freely (Frosch) in its lower portion which has been brought in from the sea coast near, a well in Qatar two meters of inside an irregular understeer. Other buildings consist of an elliptical basin provider-channel rainwater to drain water flowing one to the north and the other to the south-east has been introduced in the system to build channels pottery jars to control the amount of water outflows. Table 1 shows the presents distribution of samples in regions under study.

To get moisture free samples, they were dried in an oven at $110^{\circ} \mathrm{C}$ for 24 hours until constant dry weight [19]. The dried samples were crushed and allowed to pass through micro sieves to maintain the uniform grain size to obtain a fine-grained homogenous soil sample for the measurement [20] IAEA, 1989. About 1000 gm of the homogenized soil samples were transferred into $1000 \mathrm{ml}$ Marinelli containers. They were carefully sealed and stored for at least 30 days before gamma ray analysis to allow ${ }^{226} \mathrm{Ra}$ and its short-lived progenies to reach secular equilibrium [21]. Each sample was measured for 12 hours, by using gamma-ray spectrometry. The system consists of an $80 \%$ relatively efficiency high-purity germanium (HPGe) detector from Ortec and has a resolution of 2.0 at the $1.33 \mathrm{MeV}$ line of ${ }^{60} \mathrm{Co}$. The system was calibrated using a mixture source in soil matrix covering energies range from 59.5 to $1836 \mathrm{keV}$ in $100 \mathrm{ml}$ cylindrical plastic beaker. In order to determine the background distribution due to naturally occurring radionuclides in the environment around the detector, an empty polystyrene container was counted in the same manner as the samples. Reducing background radioactivity was achieved by surrounding the detector with a cylindrical passive lead shield of about $10 \mathrm{~cm}$ thickness. After measurement and subtraction of the background, the activity concentration was calculated [14] [22].

\subsection{Samples Analysis}

The analysis focuses on measuring ${ }^{226} \mathrm{Ra},{ }^{232} \mathrm{Th}$, and ${ }^{40} \mathrm{~K}$ activities in the soil samples. Due to the difficulty of determination the activity of ${ }^{226} \mathrm{Ra}$ and ${ }^{232}$ Th directly from their very weak energy's lines, the concentrations for both of them are determined from their decay products assuming secular equilibrium between parents and daughters. The peak analysis was conducted for the most significant energy lines for each radioisotope. The determination of activity concentration of ${ }^{226} \mathrm{Ra}$ was by using the most abundant gamma rays from the lead ${ }^{214} \mathrm{~Pb}$ at $295 \mathrm{keV}$ (18.15\%) yield and at $352 \mathrm{keV}$ (35.10\%) yield, and from ${ }^{214} \mathrm{Bi}$ being at $1764 \mathrm{keV}$ (15.1\%) yield, where the other energy lines yields are below 5\% which are too small to detect with enough confidences. The activities obtained from these three lines were averaged and the mean value was considered as the activity concentration of ${ }^{226} \mathrm{Ra}$. The specific activity of ${ }^{232}$ Th was evaluated from gamma-ray lines of ${ }^{228}$ Ac at 338.4, 911.1 and 968.9 $\mathrm{keV}$. The specific activity of ${ }^{40} \mathrm{~K}$ was determined directly from its $1460.8 \mathrm{keV}$ gamma-ray line. The activity concentrations of the natural radionuclides in the measured samples $\left(\mathrm{A}_{\mathrm{S}}\right)$ were computed using the following

Table 1. Presents distribution of samples in regions under study.

\begin{tabular}{cccc}
\hline Samples location & Sample Code & Samples number & Description \\
\hline North & a & 5 & Three hills head of archaeological excavation \\
Center & b & 5 & \\
South & c & 5 & \\
North-East & NE & 4 & Water system consists of a well-circular shape folded stones medium-sized \\
North-West & NW & 4 & \\
South-East & SE & 4 & \\
South-West & SW & 2 & \\
East & E & &
\end{tabular}


relation [23]-[26].

$$
\mathrm{A}_{\mathrm{S}}\left(\mathrm{Bq} \cdot \mathrm{kg}^{-1}\right)=\mathrm{C}_{\mathrm{a}} / \varepsilon \mathrm{P}_{\mathrm{r}} \mathrm{M}_{\mathrm{s}}
$$

where $\mathrm{C}_{\mathrm{a}}$ is the net gamma counting rate (counts per second), $\varepsilon$ the detector efficiency of the specific $\gamma$-ray, $\mathrm{P}_{\mathrm{r}}$ the absolute transition probability of Gamma-decay and $\mathrm{M}_{\mathrm{s}}$ the mass of the sample (kg).

\section{Result and Discussion}

\subsection{Activity Concentrations of ${ }^{226} \mathrm{Ra},{ }^{232} \mathrm{Th}$ and ${ }^{40} \mathrm{~K}$}

By using gamma-ray spectrometer, activity concentrations of the natural radionuclides were investigated in the soil samples. The three most important primordial radionuclides investigated in the area of interest were ${ }^{226} \mathrm{Ra}$, ${ }^{232} \mathrm{Th}$ and ${ }^{40} \mathrm{~K}$ [7]. The activity concentrations of ${ }^{226} \mathrm{Ra},{ }^{232} \mathrm{Th}$ and ${ }^{40} \mathrm{~K}$ radionuclides in soil samples are calculated and presented in Table 2. The activity of ${ }^{226} \mathrm{Ra}$ in the soil ranged from $17.34 \mathrm{~Bq} / \mathrm{kg}$ to $28.34 \mathrm{~Bq} / \mathrm{kg}$ with a mean $23 \pm 1.6 \mathrm{~Bq} / \mathrm{kg},{ }^{232} \mathrm{Th}$ ranged from $1.1 \pm 1.8 \mathrm{~Bq} / \mathrm{kg}$ to $81.0 \pm 1.7 \mathrm{~Bq} / \mathrm{kg}$ with a mean of $20 \pm 1.4$ and ${ }^{40} \mathrm{~K}$ ranged from $218 \pm 11 \mathrm{~Bq} / \mathrm{kg}$ to $255 \pm 18 \mathrm{~Bq} / \mathrm{kg}$ with a mean of $233 \pm 12 \mathrm{~Bq} / \mathrm{kg}$. The ${ }^{40} \mathrm{~K}$ activity is higher than ${ }^{232} \mathrm{Th}$ and ${ }^{226} \mathrm{Ra}$ in all measured samples. Figure 1 shows, the comparison of the mean activity concentrations values of ${ }^{232} \mathrm{Th},{ }^{226} \mathrm{Ra}$ and ${ }^{40} \mathrm{~K}(\mathrm{~Bq} / \mathrm{kg})$ in different regions of soil samples. Also, the activity concentrations of ${ }^{226} \mathrm{Ra}$, ${ }^{232} \mathrm{Th}$ and ${ }^{40} \mathrm{~K}$ in soil samples from the studied areas was compared with those from similar investigations in other countries and summary results were given in Table 3. The comparison shows that the values of soils under consideration are extremely low in accordance with others. It is found that the mean value of ${ }^{232} \mathrm{Th},{ }^{226} \mathrm{Ra}$ and ${ }^{40} \mathrm{~K}$ in the present study were lower than reported for soils of Yemen, China, Turkey and Sweden, but ${ }^{226} \mathrm{Ra}$ and ${ }^{232} \mathrm{Th}$ is found that it is higher than reported for Jeddah and Riyadh, Saudi Arabia. Where ${ }^{40} \mathrm{~K}$ is found that it is lower than reported for Jeddah, Saudi Arabia. The comparison of ${ }^{40} \mathrm{~K}$ activity concentration shows that the values of this radionuclide in the soil of United State, Yemen, Nigeria, Algeria and China are lower than the present study mean value. The variations in the concentrations of the radioactivity in the soil of the various locations of the world, depend upon the geological and geographical conditions of the area and the extent of fertilizer applied to the agriculture lands [3] [27] [28].

\subsection{Radiological Parameters}

\subsubsection{Radium Equivalent Activities ( $\mathrm{Ra}_{\mathrm{eq}}$ )}

The Gamma-ray radiation hazards due to the specified radionuclides ${ }^{226} \mathrm{Ra},{ }^{232} \mathrm{Th}$ and ${ }^{40} \mathrm{~K}$ were assessed by different indices. The most widely used radiation hazard index $\mathrm{Ra}_{\mathrm{eq}}$ is called the radium equivalent activity $\mathrm{Ra}_{\mathrm{eq}}$ [36] [37]. $\mathrm{Ra}_{\mathrm{eq}}$ is a weighted sum of activities of the above three radionuclides based on the estimation that 370

Table 2. Activity concentrations $\left({ }^{226} \mathrm{Ra},{ }^{232} \mathrm{Th}\right.$ and $\left.{ }^{40} \mathrm{~K}\right)$ in soil from a historical area Al Rakkah, Saudi Arabia.

\begin{tabular}{ccccc}
\hline Location & No. of samples & \multicolumn{2}{c}{ Mean activity concentration in (Bq/kg) } \\
\cline { 3 - 4 } & & ${ }^{226} \mathrm{Ra}$ & ${ }^{43} \mathrm{~K}$ \\
\hline North & 5 & $22.4 \pm 1.5$ & $6.6 \pm 1.4$ & $229 \pm 12$ \\
Center & 5 & $25.2 \pm 1.7$ & $81.0 \pm 1.7$ & $245 \pm 7$ \\
South & 5 & $21.1 \pm 1.4$ & $6.7 \pm 1.3$ & $255 \pm 18$ \\
North-East & 4 & $19.3 \pm 1.3$ & $4.0 \pm 1.5$ & $226 \pm 11$ \\
North-West & 4 & $23.0 \pm 1.7$ & $1.1 \pm 1.8$ & $222 \pm 10$ \\
South-East & 4 & $28.3 \pm 2.3$ & $45.7 \pm 1.5$ & $235 \pm 14$ \\
South-West & 4 & $26.6 \pm 1.8$ & $7.5 \pm 1.7$ & $230 \pm 13$ \\
East & 2 & $17.4 \pm 1.2$ & $8.0 \pm 1.3$ & $218 \pm 11$ \\
& Min & $17.4 \pm 1.2$ & $1.1 \pm 1.8$ & $218 \pm 11$ \\
& Max & $28.3 \pm 2.3$ & $81.0 \pm 1.7$ & $255 \pm 18$ \\
& Average & $23 \pm 1.6$ & $20 \pm 1.4$ & $233 \pm 12$ \\
\hline
\end{tabular}




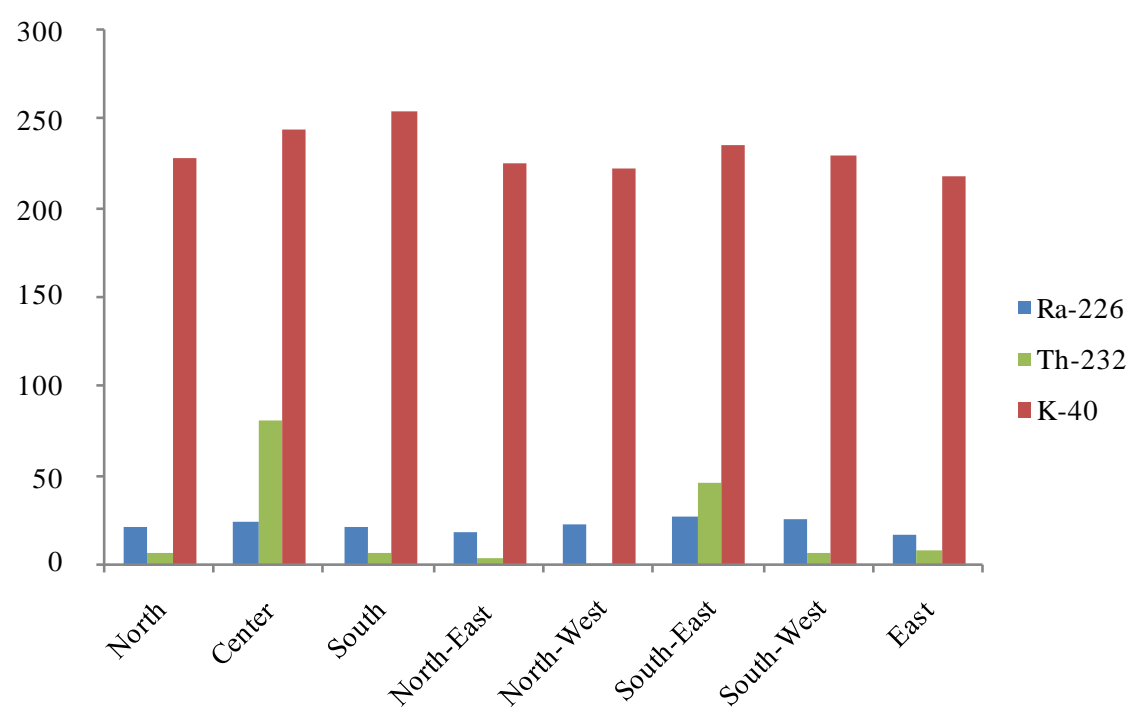

Figure 1. Average activity of ${ }^{226} \mathrm{Ra},{ }^{232} \mathrm{Th}$ and ${ }^{40} \mathrm{~K}(\mathrm{~Bq} / \mathrm{kg})$ in soil from different regions of a historical area, Al Rakkah, Saudi Arabia.

Table 3. Comparison of natural radioactivity concentration $\left(\mathrm{Bq} \cdot \mathrm{kg}^{-1}\right)$ in the soil Samples for present study with previous study reported from different countries of the world.

\begin{tabular}{|c|c|c|c|c|}
\hline \multirow{2}{*}{ Country } & \multicolumn{3}{|c|}{ Mean activity concentration $\left(\mathrm{Bq} \cdot \mathrm{kg}^{-1}\right)$} & \multirow{2}{*}{ References } \\
\hline & ${ }^{226} \mathrm{Ra}$ & ${ }^{232} \mathrm{Th}$ & ${ }^{40} \mathrm{~K}$ & \\
\hline Al Rakkah East of Saudi Arabia & 23 & 20 & 233 & Present study \\
\hline Riyadh, Center of Saudi Arabia & 14.5 & 11 & 225 & [28] \\
\hline Tayma, north west of Saudi & 30.77 & 27.59 & 161.8 & [14] \\
\hline Albaha, South of Saudi Arabia & 37 & 32 & 343 & [30] \\
\hline Jeddah, West of Saudi Arabia & 9.3 & 7.4 & 369 & [31] \\
\hline Kuwai, North region & 66.6 & 11.3 & 384.5 & [15] \\
\hline Kuwai, south region & 13.6 & 2.4 & 110.4 & [15] \\
\hline Oman & 29.7 & 15.9 & 225 & {$[16]$} \\
\hline Qatar & 23.2 & 4.5 & 127.1 & {$[32]$} \\
\hline Jordan & 49 & 27 & 291 & [13] \\
\hline Syria & 23 & 20 & 270 & [3] \\
\hline Iran & 28 & 22 & 640 & [3] \\
\hline India & 26.4 & 51.2 & 5.6 & [9] \\
\hline Pakistan & 25.8 & 49.2 & 561.6 & [7] \\
\hline Pakistan & 73.9 & 152.2 & 325.3 & {$[5]$} \\
\hline China & 38.5 & 54.6 & 584 & [10] \\
\hline Japan & 29 & 28 & 310 & [3] \\
\hline Yemen & 44 & 58 & 823 & [33] \\
\hline Egypt, National range & 37 & 18 & 320 & [3] \\
\hline Nigeria & 7.8 & 29.4 & 229 & [34] \\
\hline Turkey & 37 & 40 & 667 & [35] \\
\hline Algeria & 50 & 25 & 370 & [3] \\
\hline Sweden & 42 & 42 & 680 & [3] \\
\hline China & 32 & 41 & 440 & [3] \\
\hline India & 41 & 29 & 400 & [3] \\
\hline United State & 40 & 35 & 370 & [3] \\
\hline World average & 32 & 45 & 420 & [3] \\
\hline
\end{tabular}


$\mathrm{Bq} / \mathrm{kg}$ of ${ }^{226} \mathrm{Ra}, 259 \mathrm{~Bq} / \mathrm{kg}$ of ${ }^{232} \mathrm{Th}$ and $4810 \mathrm{~Bq} / \mathrm{kg}$ of ${ }^{40} \mathrm{~K}$ produce the same $\gamma$-ray dose rates. $\mathrm{Ra}_{\mathrm{eq}}$ is given by

$$
\mathrm{Ra}_{\mathrm{eq}}=\mathrm{A}_{\mathrm{Ra}}+\left(\mathrm{A}_{\mathrm{Th}} \times 1.43\right)+\left(\mathrm{A}_{\mathrm{K}} \times 0.077\right)
$$

The formula is based on the assumption that $370 \mathrm{~Bq} \cdot \mathrm{kg}^{-1}$ of ${ }^{226} \mathrm{Ra}, 259 \mathrm{~Bq} \cdot \mathrm{kg}^{-1}$ of ${ }^{232} \mathrm{Th}^{-1}$ and $481 \mathrm{~Bq} \cdot \mathrm{kg}^{-1}$ of ${ }^{40} \mathrm{~K}$ produce the same gamma-ray dose rate [38] A value of $370 \mathrm{~Bq} \cdot \mathrm{kg}^{-1}$ corresponds to $1 \mathrm{mSv} \cdot \mathrm{y}^{-1}$. The radium equivalent concept allows a single index or number which is a widely used hazard index to describe the gamma output from different mixtures of uranium, thorium and potassium in the soil samples from different locations. The calculated values are varied from 35.8 to $159.9 \mathrm{~Bq} / \mathrm{kg}$ with an average of $69.52 \mathrm{~Bq} / \mathrm{kg}$ (Table 4). These values are lower than the permissible maximum value of $370 \mathrm{~Bq} \cdot \mathrm{kg}^{-1}[2]$.

\subsubsection{Hazard Index $(\mathrm{H})$}

The external hazard index for samples under investigation is given by the following equation [36]

$$
\mathrm{H}_{\mathrm{ex}}=\mathrm{C}_{\mathrm{Ra}} / 370 \mathrm{~Bq} \cdot \mathrm{kg}^{-1}+\mathrm{C}_{\mathrm{Th}} / 259 \mathrm{~Bq} \cdot \mathrm{kg}^{-1}+\mathrm{C}_{\mathrm{K}} / 4810 \mathrm{~Bq} \cdot \mathrm{kg}^{-1}
$$

In addition, the external irradiation radon and its short-lived products are also hazardous to the respiratory organs. The values of outdoor radiation hazard index $\left(\mathrm{H}_{\mathrm{ex}}\right)$ vary from 0.10 to 0.43 with a mean value of 0.2 , which all values are less than the critical value of unity. Therefore, based on these results of radium equivalent activity and external hazard indices, one can conclude that there is no health hazard from the soil of Al-Rakkah region. External and internal hazard indices calculated for soils. The health hazard for the population in the environment results mostly from the alpha-radioactive nuclides (radon, thorn and their decay products) being present in the air. To estimate the population internal exposure associated with the natural radio nuclides in the soil, the internal hazard index $\left(\mathrm{H}_{\text {in }}\right)$ was calculated according to the following equation [39]:

$$
\mathrm{H}_{\text {in }}=\mathrm{C}_{\mathrm{Ra}} / 185+\mathrm{C}_{\mathrm{Th}} / 259+\mathrm{C}_{\mathrm{K}} / 4810<1
$$

The criterion of this model considers that the maximum value of $\mathrm{H}_{\text {in }}$ equal to unity. The values of indoor radiation hazard index $\left(\mathrm{H}_{\text {in }}\right)$ vary from 0.17 to 0.5 with a mean value of 0.2 , which all values are less than the critical value of unity and are presented in Table 4.

\subsubsection{Representative Level Index}

Radiation hazards due to the specified radionuclides of ${ }^{226} \mathrm{Ra},{ }^{232} \mathrm{Th}$ and ${ }^{40} \mathrm{~K}$ were assessed by another index called representative level index, $I_{\gamma r}$. The following equation was applied to calculate $\mathrm{I}_{\gamma \mathrm{r}}$ for soil samples under investigation.

$$
\mathrm{I}_{\gamma \mathrm{r}}=(1 / 150) C_{\mathrm{Ra}}+(1 / 100) C_{\mathrm{Th}}+(1 / 1500) C_{\mathrm{K}}
$$

\begin{tabular}{|c|c|c|c|c|c|}
\hline \multirow[t]{2}{*}{ Location } & \multirow{2}{*}{ Sample No. } & \multicolumn{4}{|c|}{ Radiological hazards } \\
\hline & & $\begin{array}{l}\text { Radium equivalent activity } \\
\qquad \mathrm{Ra}_{\text {eq }}(\mathrm{Bq} / \mathrm{kg})\end{array}$ & $\begin{array}{c}\text { External hazard } \\
\text { index } \mathrm{H}_{\mathrm{ex}}\end{array}$ & $\begin{array}{c}\text { Internal hazard } \\
\text { index } \mathrm{H}_{\text {in }}\end{array}$ & $\begin{array}{l}\text { Representative level } \\
\text { index } \mathrm{I}_{\gamma \mathrm{r}}\end{array}$ \\
\hline North & 5 & 49.4 & 0.1 & 0.19 & 0.37 \\
\hline Center & 5 & 159.9 & 0.4 & 0.50 & 1.14 \\
\hline South & 5 & 50.4 & 0.1 & 0.19 & 0.38 \\
\hline North-East & 4 & 42.4 & 0.1 & 0.17 & 0.32 \\
\hline North-West & 4 & 41.7 & 0.1 & 0.17 & 0.31 \\
\hline South-East & 4 & 111.8 & 0.3 & 0.38 & 0.80 \\
\hline South-West & 4 & 55.0 & 0.1 & 0.22 & 0.41 \\
\hline \multirow[t]{4}{*}{ East } & 2 & 45.6 & 0.1 & 0.17 & 0.34 \\
\hline & Min & 35.8 & 0.1 & 0.17 & 0.31 \\
\hline & Max & 159.9 & 0.4 & 0.5 & 1.14 \\
\hline & Average & 69.52 & 0.2 & 0.2 & 0.5 \\
\hline
\end{tabular}

Table 4. Average radiological hazards $\left(\mathrm{H}_{\mathrm{ex}}, \mathrm{H}_{\mathrm{in}}, I_{\mathrm{rr}}\right.$ and $\mathrm{Ra}_{\mathrm{eq}}$ ) in soil from Al-Rakkah. 
where $\mathrm{C}_{\mathrm{Ra}}, C_{\mathrm{Th}}$ and $C_{\mathrm{K}}$ are the specific activities of ${ }^{226} \mathrm{Ra},{ }^{232} \mathrm{Th}$ and ${ }^{40} \mathrm{~K}$ in $\mathrm{Bq} / \mathrm{kg}$, respectively [22]. $\mathrm{I}_{\gamma r}$ varies from 0.31 to 1.14 with a mean value of 0.5 as shown in Table 3 . The average hazard index $\left(\mathrm{H}_{\mathrm{ex}}, \mathrm{H}_{\mathrm{in}}\right)$ and representative level index, $\mathrm{I}_{\mathrm{r} r}$ are plotted in Figure 2.

\subsubsection{Absorbed Dose Rate}

The absorbed gamma dose rates $\mathrm{D}_{\mathrm{R}}\left(\mathrm{nG} \cdot \mathrm{h}^{-1}\right)$ in air at $1 \mathrm{~m}$ above the ground surface for the uniform distribution of radionuclides were calculated based on guidelines provided by [40] UNSCEAR (2000).

$$
\mathrm{D}_{\mathrm{R}}\left(\mathrm{nG} \cdot \mathrm{h}^{-1}\right)=0.427 \mathrm{C}_{\mathrm{Ra}}+0.623 \mathrm{C}_{\mathrm{Th}}+0.043 \mathrm{C}_{\mathrm{K}}
$$

where $\mathrm{C}_{\mathrm{Ra}}, \mathrm{C}_{\mathrm{Th}}$ and $\mathrm{C}_{\mathrm{K}}$ are the activity concentrations $\left(\mathrm{Bq} \cdot \mathrm{kg}^{-1}\right)$ of ${ }^{226} \mathrm{Ra},{ }^{232} \mathrm{Th}$ and ${ }^{40} \mathrm{~K}$ respectively, in the samples. The absorbed dose rate expresses the received dose in the open air from the radiation emitted from radionuclides concentration in Environmental materials. Also, it is the first major step for evaluating the health risk and is expressed in gray (Gy).

The calculated total absorbed dose of samples are tabulated in Table 5. It is observed that the absorbed dose rate calculated from activity concentration of ${ }^{226} \mathrm{Ra},{ }^{232} \mathrm{Th}$ and ${ }^{40} \mathrm{~K}$ ranges between 20.06 to 71.28 with an average $32.30 \mathrm{~Bq} \cdot \mathrm{kg}^{-1}$.

\subsubsection{The Annual Effective Dose Equivalent (AEDE)}

The annual effective dose equivalent (AEDE) was calculated from the absorbed dose by applying the dose conversion factor of $0.7 \mathrm{~Sv} \cdot \mathrm{Gy}^{-1}$ with an outdoor occupancy factor of 0.2 and 0.8 for indoor [3] [39] UNSCEAR, 1993 \& UNSCEAR, 2000.

$$
\begin{aligned}
& (\text { AEDE })_{\text {outdoor }}=\mathrm{D}\left(\mathrm{nG} \cdot \mathrm{h}^{-1}\right) \times 8760\left(\mathrm{~h} \cdot \mathrm{y}^{-1}\right) \times 0.7 \times\left(10^{3} \mathrm{mSv} / \mathrm{nGy} 10^{9}\right) \times 0.2 \\
& \text { Equation }(7) \text { simplifies into }(\mathrm{AEDE})_{\text {outdoor }}=\mathrm{D} \times 1.226 \times 10^{-3}\left(\mathrm{mSv} \cdot \mathrm{y}^{-1}\right) \\
& (\text { AEDE })_{\text {indoor }}=\mathrm{D}\left(\mathrm{nG} \cdot \mathrm{h}^{-1}\right) \times 8760\left(\mathrm{~h} \cdot \mathrm{y}^{-1}\right) \times 0.7 \times\left(10^{3} \mathrm{mSv} / \mathrm{nGy} 10^{9}\right) \times 0.8 \\
& \text { Equation (8) simplifies into }(\mathrm{AEDE})_{\text {indoor }}=\mathrm{D} \times 4.905 \times 10^{-3}\left(\mathrm{mSv} \cdot \mathrm{y}^{-1}\right)
\end{aligned}
$$

To estimate annual effective doses, account must be taken of (a) the conversion coefficient from absorbed dose in air to effective dose and (b) the indoor occupancy factor. The average numerical values of those parameters vary with the age of the population and the climate at the location considered. A report by the UNSCEAR Committee 1993) [39], used $0.7 \mathrm{~Sv} \cdot \mathrm{Gy}^{-1}$ for the conversion coefficient from absorbed dose in air to effective dose received by adults and 0.8 for the indoor occupancy factor, i.e. the fraction of time spent indoors and outdoors is 0.8 and 0.2 , respectively. The resulting worldwide average of the annual effective dose is 0.48 $\mathrm{mSv}$, with the results for individual countries being generally within the $0.3-0.6 \mathrm{mSv}$ range. For children and infants, the values are about $10 \%$ and $30 \%$ higher, in direct proportion to an increase in the value of the conversion coefficient from absorbed dose in air to effective dose [3].

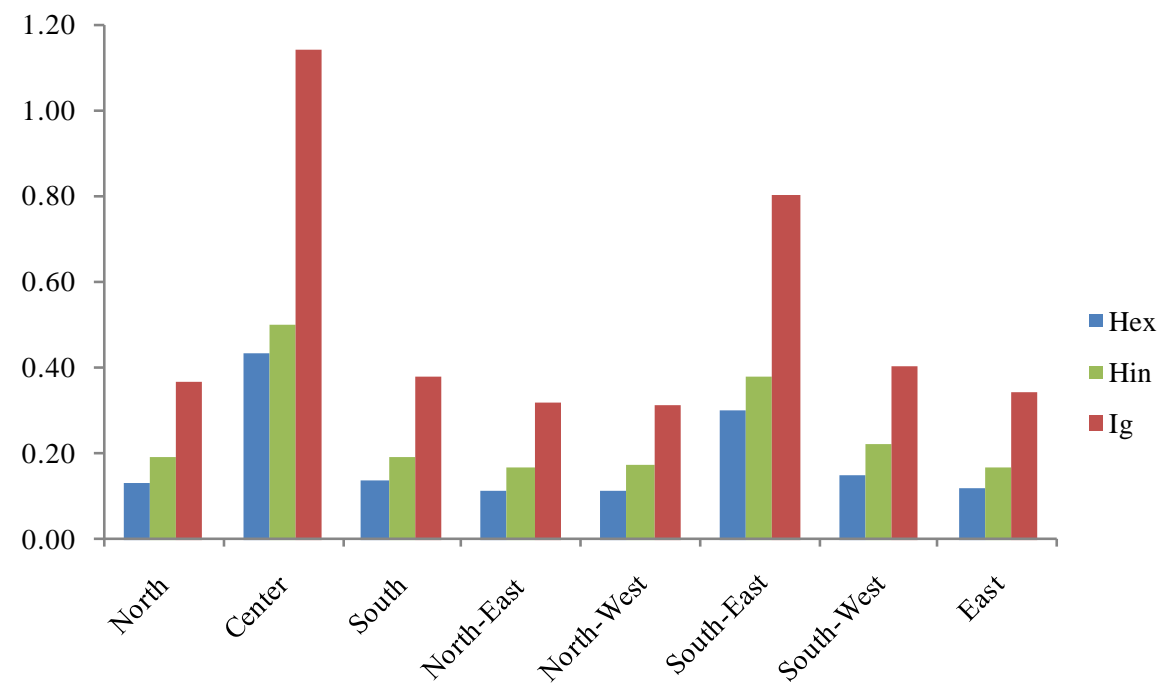

Figure 2. Average activity of $\mathrm{H}_{\mathrm{ex}}, \mathrm{H}_{\mathrm{in}},(\mathrm{Bq} / \mathrm{kg})$ and $\mathrm{I}_{\mathrm{r}}$ in soil from different regions of a historical area, Al Rakkah, Saudi Arabia. 
Table 5. Air-absorbed dose rates and annual effective doses calculated for surface soil samples collected from Al-Rakkah, Saudi Arabia.

\begin{tabular}{|c|c|c|c|c|c|c|c|}
\hline \multirow[t]{2}{*}{ Location } & \multirow{2}{*}{ No. sample } & \multicolumn{4}{|c|}{ Absorbed dose $\left(\mathrm{nGh}^{-1}\right)$} & \multicolumn{2}{|c|}{ Annual effective dose (mSv/y) } \\
\hline & & ${ }^{226} \mathrm{Ra}$ & ${ }^{232} \mathrm{Th}$ & ${ }^{40} \mathrm{~K}$ & Total & $(\mathrm{AEDE})_{\text {outdoor }}$ & $(\mathrm{AEDE})_{\text {indoor }}$ \\
\hline North & 5 & 9.56 & 4.08 & 9.85 & 23.49 & 0.03 & 0.12 \\
\hline Center & 5 & 10.77 & 50.46 & 10.54 & 71.78 & 0.09 & 0.35 \\
\hline South & 5 & 9.02 & 4.17 & 10.98 & 24.18 & 0.03 & 0.12 \\
\hline North-East & 4 & 8.22 & 2.49 & 9.73 & 20.45 & 0.03 & 0.10 \\
\hline North-West & 4 & 9.80 & 0.70 & 9.56 & 20.06 & 0.02 & 0.10 \\
\hline South-East & 4 & 12.10 & 28.47 & 10.12 & 50.70 & 0.06 & 0.25 \\
\hline South-West & 4 & 11.34 & 4.67 & 9.90 & 25.91 & 0.03 & 0.13 \\
\hline \multirow[t]{4}{*}{ East } & 2 & 7.40 & 4.98 & 9.39 & 21.78 & 0.03 & 0.11 \\
\hline & Min & 7.40 & 0.70 & 9.39 & 20.06 & 0.02 & 0.10 \\
\hline & Max & 12.10 & 50.46 & 10.98 & 71.78 & 0.09 & 0.35 \\
\hline & Average & 9.8 & 12.5 & 10 & 32.3 & 0.04 & 0.16 \\
\hline
\end{tabular}

As shown in Table 5 , the annual effective dose equivalent from outdoor terrestrial gamma radiation ranged from $0.02 \mathrm{mSv} \cdot \mathrm{y}^{-1}$ to $0.09 \mathrm{mSv} \cdot \mathrm{y}^{-1}$ with a mean value of $0.04 \mathrm{mSv} \cdot \mathrm{y}^{-1}$. Also, for indoor exposure, the annual effective dose equivalent had a range from $0.10 \mathrm{mSv} \cdot \mathrm{y}^{-1}$ to $0.35 \mathrm{mSv} \cdot \mathrm{y}^{-1}$ with a mean value of $0.16 \mathrm{mSv} \cdot \mathrm{y}^{-1}$. The corresponding world average value is $0.41 \mathrm{mSv} \cdot \mathrm{y}^{-1}$ of which $0.07 \mathrm{mSv} \cdot \mathrm{y}^{-1}$ is from outdoor and 0.34 $\mathrm{mSv} \cdot \mathrm{y}^{-1}$ from indoor exposure [2]. Therefore, the study area is still in the zones of normal radiation level, which leaves the soil radioactivity there less a threat to the environment as well as the human health.

\section{Conclusion}

It is important to determine background radiation levels in order to evaluate the health hazards. The method of gamma spectrometry had been used to measure the radioactivity concentration of 33 soil samples collected from a new historical area which was discovered in east of Saudi Arabia at 2009 G, Called Al-Rakkah. From this study, the mean activity concentrations for ${ }^{226} \mathrm{Ra},{ }^{232} \mathrm{Th}$ and ${ }^{40} \mathrm{~K}$ are 23,20 and $233 \mathrm{~Bq} \cdot \mathrm{kg}^{-1}$ respectively. Overall, the study showed that the measured values are lower than those in the world wide soil. The mean value of total absorbed dose rate is $32.69 \mathrm{nGy} / \mathrm{h}$, which is below the corresponding population-weight (world average) value of $65 \mathrm{nGy} \cdot \mathrm{h}^{-1}$. Annual effective gamma doses are lower than the world's average. The value of $\mathrm{Ra}_{\mathrm{eq}}$ activity was found to be less than $370 \mathrm{~Bq} \cdot \mathrm{kg}^{-1}$; the external hazard indices were found to be less than the acceptable limit of unity. Therefore, the study area is still within the zone of normal radiation level, which leaves the soil radioactivity there less of a threat to the environment as well as the human health. However, this data may provide a general background level for the area studied and may also serve as a guideline for future measurement and assessment of possible radiological risks to human health in this region.

\section{References}

[1] EPA (2007) United States. Ionizing Radiation, Fact book. Enviromental Protection Agency, March 2007. EPA-402-F06-061.

[2] UNSCEAR (1988) United Nations Scientific Committee on the effects of Atomic Radiation: Sources, Effects and Risks of Ionizing Radiation, Report to the General Assembly, United Nations, New York.

[3] UNSCEAR (2000) Report to General Assembly, with Scientific Annexes, Sources and Effects of Ionizing Radiation, United Nations, New York.

[4] Sroor, A., El-Bahi, S.M., Ahmed, F. and Abdel-Haleem, A.S. (2001) Natural Radioactivity and Radon Exhalation Rate of Soil in Southern Egypt. Applied Radiation and Isotopes, 55, 873-879. http://dx.doi.org/10.1016/S0969-8043(01)00123-3 
[5] Rahmana, Md.R., Shi, Z.H. and Chongfa, C. (2009) Soil Erosion Hazard Evaluation-An Integrated Use of Remote Sensing, GIS and Statistical Approaches with Biophysical Parameters towards Management Strategies. Ecological Modelling, 220, 1724-1734. http://dx.doi.org/10.1016/j.ecolmodel.2009.04.004

[6] Kurnaz, A., Küçükömeroğlu, B., Keser, R., Okumusoglu, N.T., Korkmaz, F., Karahan, G. and Çevik, U. (2007) Determination of Radioactivity Levels and Hazards of Soil and sediment Samples in Firtına Valley (Rize, Turkey). Applied Radiation and Isotopes, 65, 1281-1289. http://dx.doi.org/10.1016/j.apradiso.2007.06.001

[7] Akhtar, N., Tafail, M., Ashraf, M. and Iqbal, M. (2005) Measurement of Environmental Radioactivity for Estimation of Radiation Exposure from Saline Soil of Lahore, Pakistan. Radiation Measurements, 39, 11-14. http://dx.doi.org/10.1016/j.radmeas.2004.02.016

[8] Ramli, A.T., Hussein, A.W.M.A. and Wood, A.K. (2005) Environmental 238U and 232Th Concentration Measurements in an Area of High Level Natural Background Radiation at Palong, Johor, Malaysia. Journal of Environmental Radioactivity, 80, 287-304. http://dx.doi.org/10.1016/j.jenvrad.2004.06.008

[9] Rani, A. and Surinder, S. (2005) Natural Radioactivity Levels in Soil Samples from Some Areas of Himachal Pradesh, India Using $\gamma$-Ray Spectrometry. Atmospheric Environment, 39, 6306-6314. http://dx.doi.org/10.1016/j.atmosenv.2005.07.050

[10] Yang, Y.-X., Wu, X.-M., Jiang, Z.-Y., Wang, W.-X., Lu, J.-G., Lin, J., Wang, L.-M. and Hsia, Y.-F. (2005) Radioactivity Concentrations in Soils of the Xiazhuang Granite Area, China. Applied Radiation and Isotopes, 63, 255-259. http://dx.doi.org/10.1016/j.apradiso.2005.02.011

[11] Banzi, F.P., Kifanga, L.D. and Bundala, F.M. (2000) Natural Radioactivity and Radiation Exposure at the Minjingu Phosphate Mine in Tanzania. Journal of Radiological Protection, 20, 41-52. http://dx.doi.org/10.1088/0952-4746/20/1/305

[12] Karahan, G. and Bayulken, A. (2000) Assessment of Gamma Dose Rates around Istanbul (Turkey). Journal of Environmental Radioactivity, 47, 213-221. http://dx.doi.org/10.1016/S0265-931X(99)00034-X

[13] Al-Hamarneh, I.F. and Awadallah, M.I. (2009) Soil Radioactivity Levels and Radiation Hazard Assessment in the Highlands of Northern Jordan. Radiation Measurements, 44, 102-110. http://dx.doi.org/10.1016/j.radmeas.2008.11.005

[14] Zarie, K.A. and Al Mugren, K.S. (2010) Measurement of Natural Radioactivity and Assessment of Radiation Hazard in Soil Samples from Tammy Area (KSA). Isotope and Radiation Research, 42, 1-9.

[15] Saad, H.R. and Al-Azmi, D. (2002) Radioactivity Concentrations in Sediments and Their Correlation to the Coastal Structure in Kuwait. Applied Radiation and Isotopes, 56, 991-997. http://dx.doi.org/10.1016/S0969-8043(02)00061-1

[16] Goddard, C.C. (2001) Measurement of Outdoor Terrestrial Gamma Radiation in the Sultanate of Oman. Health Physics, 82, 869-874. http://dx.doi.org/10.1097/00004032-200206000-00016

[17] Akhtar, N., Tufail, M., Ashraf, M. and Mohsin Iqbal, M. (2005) Measurement of Environmental Radioactivity for Estimation of Radiation Exposure from Saline Soil of Lahore, Pakistan. Radiation Measurements, 39, 11-14. http://dx.doi.org/10.1016/j.radmeas.2004.02.016

[18] Alhajerey, M.Y. (2001) Report on Acts of Archaeological Excavations Alkhobar Site, The First Season, 200911/16/ 1430 e - 29/04/1431 e, General Authority for Tourism and Antiquities Antiquities and Museums Sector, Kingdom of Saudi Arabia.

[19] Veiga, R., Sanches, N., Anjos, R.M., Macario, K., Bastos, J., Iguatemy, M., Aguiar, J.G., Santos, A.M.A., Mosquera, B., Carvalho, C., Baptista Filho, M. and Umisedo, N.K. (2006) Measurement of Natural Radioactivity in Brazilian Beach Sands. Radiation Measurements, 41, 189-196. http://dx.doi.org/10.1016/j.radmeas.2005.05.001

[20] IAEA (1989) Measurement of Radionuclides in Food and the Environment. IAEA Technical Report Series No. 295, Vienna.

[21] Mollah, A.S., Rahman, M.M., Kodlus, M.A., Husain, S.R. and Malek, M.A. (1987) Measurement of High Natural Background Radiation Levels by TLD at Cox’s Bazar Coastal Areas in Bangladesh. Radiation Protection Dosimetry, 18, 39-41.

[22] El-Taher, A. and Madkour, H.A. (2011) Distribution and Environmental Impacts of Metals and Natural Radionuclides in Marine Sediments In-Front of Different Wadies Mouth along the Egyptian Red Sea Coast. Applied Radiation and Isotopes, 69, 550-558. http://dx.doi.org/10.1016/j.apradiso.2010.11.010

[23] Abbady, A.G.E. (2004) Estimation of Radiation Hazard Indices from Sedimentary Rocks in Upper Egypt. Applied Radiation and Isotopes, 60, 111-114. http://dx.doi.org/10.1016/j.apradiso.2003.09.012

[24] Uosif, M.A.M., El-Taher, A. and Abbady, A.G.E. (2008) Radiological Significance of Beach Sand Used for Climatotherapy from Safaga, Egypt. Radiation Protection Dosimetry, 131, 331-339.

http://dx.doi.org/10.1093/rpd/ncn175

[25] Al-Sulaiti, H., Tabassum, N., Al Mugren, K.S., Alkhomashi, N., Al-Dahan, N., Al-Dosari, M., Bradley, D.A., Bukhari, 
S., Matthews, M., Regan, P.H., Santawamaitre, T., Malain, D. and Habib, A. (2012) Determination of the Natural Radioactivity Levels in North West of Dukhan, Qatar Using High-Resolution Gamma-Ray Spectrometry. Applied Radiation and Isotopes, 70, 1344-1350. http://dx.doi.org/10.1016/j.apradiso.2011.11.015

[26] El-Taher, A. and Al-Zahrani, J.H. (2014) Radioactivity Measurements and Radiation Dose Assessments in Soil of Al-Qassim Region, Saudi Arabia. Indian Journal of Pure and Applied Physics, 52, 147-154.

[27] NCRP (1975) Background Radiation in the USA Recommendation of the National Council of Radiation and Measurements. Report No. 45.

[28] Tzortzis, M., Tsertos, H., Christofider, S. and Christodoulides, G. (2003) Gamma-Ray Measurements of Naturally Occurring Radioactive Samples from Cyprus Characteristic Geological Rocks. Radiation Measurements, 37, 221-229. http://dx.doi.org/10.1016/S1350-4487(03)00028-3

[29] Al-Aamer, A.S. (2008) Assessment of Human Exposures to Natural Sources of Radiation in Soil of Riyadh, Saudi Arabia. Turkish Journal of Engineering \& Environmental Sciences, 32, 229-234.

[30] Al-Zahrani, J.H. (2012) Radioactivity Measurements and Radiation Dose Assessments in Soil of Albaha Region (Saudi Arabia). Life Science Journal, 9, 2391-2397.

[31] Abdul-Majid, S. and Abulfaraj, W. (1992) Radioactivity Concentration in Soil in Jeddah Area, Saudi Arabia. Journal of Environmental Science and Health. Part A, 27, 105-116. http://dx.doi.org/10.1080/10934529209375719

[32] Nasir, T., Al-Sulaiti, H. and Regan, P.H. (2012) Assessment of Radioactivity in Some Soil Samples of Qatar by Gamma-Ray Spectroscopy and the Derived Dose Rates. Pakistan Journal of Scientific and Industrial Research. Series A: Physical Sciences, 55, 128-134.

[33] Abd El-mageed, A.I., El-Kamel, A.H., Abbady, A., Harb, S., Youssef, A.M.M. and Saleh, I.I. (2011) Assessment of Natural and Anthropogenic Radioactivity Levels in Rocks and Soils in the Environments of Juban Town in Yemen. Radiation Physics and Chemistry, 80, 710-715. http://dx.doi.org/10.1016/j.radphyschem.2011.02.025

[34] Kolo, M.T., Baba-Kutigi, A.N., Olarinoye, I.O. and Sharifat, I. (2012) Assessment of Natural Radioactivity Levels and Radiation Hazards in the Tertiary Institutions in Minna, Niger State, Nigeria. Continental Journal of Environmental Sciences, 6, 25-31.

[35] Taskin, H., Karavus, M., Ayb, P., Topuzoglu, A., Hidiroglu, S. and Karahan, G. (2009) Radionuclide Concentrations in Soil and Lifetime Cancer Risk Due to Gamma Radioactivity in Kirklareli, Turkey. Journal of Environmental Radioactivity, 100, 49-53. http://dx.doi.org/10.1016/j.jenvrad.2008.10.012

[36] Krieger, R. (1981) Radioactivity of Construction Materials. Betonwerk und Fertigteil-Technik/Concrete Precasting Plant and Technology, 47, 468-446.

[37] Beretka, J. and Mathew, P.J. (1985) Natural Radioactivity of Australian Building Materials, Industrial Wastes and by Products. Health Physics, 48, 87-95. http://dx.doi.org/10.1097/00004032-198501000-00007

[38] Stranden, E. (1976) Some Aspects on Radioactivity of Building Materials. Physica Norvegica, 8, 167-173.

[39] Venturini, L. and Nisti, M.B. (1997) Natural Radioactivity of Some Brazilian Building Materials. Radiation Protection Dosimetry, 71, 227-229. http://dx.doi.org/10.1093/oxfordjournals.rpd.a032058

[40] UNSCEAR-United Nations Scientific Committee on the Effects of Atomic Radiation (1993) Sources, Effects and Risks of Ionizing Radiation. United Nations, New York. 